Sādhanā Vol. 40, Part 1, February 2015, pp. 139-153. (C) Indian Academy of Sciences

\title{
Simulation and comparison of perturb and observe and incremental conductance MPPT algorithms for solar energy system connected to grid
}

\author{
SACHIN VRAJLAL RAJANI ${ }^{1, *}$ and VIVEK J PANDYA ${ }^{2}$ \\ ${ }^{1}$ Department of Electrical Engineering, R.K. University, Rajkot 360020, India \\ ${ }^{2}$ School of Technolgy, Pandit Dindayal Petroleum University, Gandhinagar \\ 382007, India \\ e-mail: sachin_3541@rediffmail.com
}

MS received 5 November 2012; revised 25 October 2014; accepted 27 October 2014

\begin{abstract}
Solar energy is a clean, green and renewable source of energy. It is available in abundance in nature. Solar cells by photovoltaic action are able to convert the solar energy into electric current. The output power of solar cell depends upon factors such as solar irradiation (insolation), temperature and other climatic conditions. Present commercial efficiency of solar cells is not greater than $15 \%$ and therefore the available efficiency is to be exploited to the maximum possible value and the maximum power point tracking (MPPT) with the aid of power electronics to solar array can make this possible. There are many algorithms proposed to realize maximum power point tracking. These algorithms have their own merits and limitations. In this paper, an attempt is made to understand the basic functionality of the two most popular algorithms viz. Perturb and Observe (P \& O) algorithm and Incremental conductance algorithm. These algorithms are compared by simulating a $100 \mathrm{~kW}$ solar power generating station connected to grid. MATLAB M-files are generated to understand MPPT and its dependency on insolation and temperature. MATLAB Simulink software is used to simulate the MPPT systems. Simulation results are presented to verify these assumptions.
\end{abstract}

Keywords. Solar array; insolation; MPPT; modelling, P \& O; incremental conductance.

\section{Introduction}

Global warming, air pollution and rising fossil fuel prices have become mind-boggling for the scientists, environmental engineers and even for the whole world today. The race of industrialization is showing its bitter consequences. The emissions especially from thermal power plants and vehicles are of major concern. With the rising population, the energy needs are increasing

*For correspondence 
day by day and that is to be fulfilled by commissioning new power plants. In this context, Photovoltaic (PV) power generation has an important role to play because it is a green source. The only emissions associated with PV power generation are those from production of its components. After their installation they generate electrical energy with the help of solar irradiation without emitting greenhouse gases. These modules make PV arrays. PV arrays can be installed at the places which, in general, are of no use e.g., roofs, desserts, remote locations, canal tops, land of no use and many more (Enslin et al 1997; Szczesny et al 1985; Hohm 2000; Xiao 2011).

A power source will deliver its maximum power to a load when the power source and load impedance are same (Maximum power transfer theorem). Unfortunately, batteries are far from the ideal load for a solar array and the mismatch results in major efficiency losses (Armstrong \& Hurley 2004). Consider a PV array designed to charge 12 Volt batteries which delivers maximum power at an operating voltage around 17 Volts.

Charging in the simplest manner can be carried out by connecting PV array directly to the battery. As battery itself is a power source, it presents an opposing voltage to the PV array. This pulls the operating voltage of the array down to the voltage of the discharged battery and this is far from the optimum operating point of the array.

Figure 1 shows the performance of a17 Volt, 4.4 Amp, 75 Watt PV array used to charge a 12 Volt battery. If the actual battery voltage is 12 Volts, as seen from figure 1, the resulting current will only be about $2.5 \mathrm{Amps}$ and the power delivered by the array will be just over 50 Watts rather than the specified 75 Watts: that means an efficiency loss of over 30\%. Maximum Power Point Tracking is designed to overcome this problem. The power tracker module is a form of voltage regulator which is placed between the PV array and the battery. It presents an ideal load to the PV array allowing it to operate at its optimum voltage, in this case 17 Volts, delivering its full 75 Watts regardless of the battery voltage. A variable DC/DC converter in the module automatically adjusts the DC output from the module to match with the battery voltage of 12 Volts. As the voltage steps down in the DC/DC converter, the current will step up in the same ratio. Thus, the charging current will be $17 / 12 * 4.4=6.2$ Amps and, assuming no losses in the module, the power delivered to the battery will be $12 * 6.23=$ the full 75 Watts generated by the

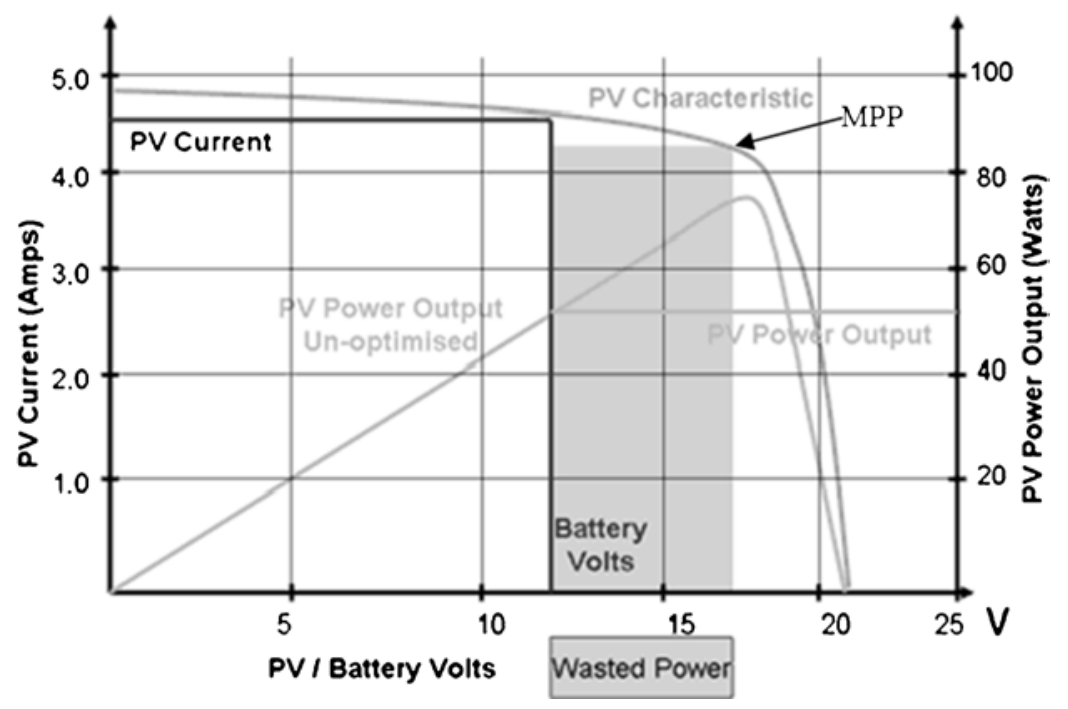

Figure 1. PV array battery charging power transfer (Armstrong \& Hurley 2004). 
PV array. In practice, the converter losses could be as high as $10 \%$. Nevertheless, a substantial efficiency improvement is possible (Armstrong \& Hurley 2004).

It is not enough, however to match the voltage at the specified maximum power point (MPP) of the PV array to the varying battery voltage as the battery charges up. Due to change in the ambient temperature or solar insolation falling on PV array, the operating characteristics of the PV array is constantly changing and therefore MPP of PV also changes. Thus, we have a moving reference point and a moving target. For optimum power transfer, the system needs to track the MPP as the solar intensity and ambient temperature changes in order to provide a dynamic reference point to the voltage regulator. The power delivered by PV arrays depends upon solar irradiance (insolation), temperature and current drawn from the solar cells. Maximum Power Point Tracking (MPPT) is power electronics based method to obtain maximum power under varying irradiation and temperature conditions from PV arrays.

\section{Basic block diagram of MPPT system}

As discussed earlier, MPPT is nothing but a process of making source impedance equal to the load impedance and this task can be achieved in real time by DC-DC converter. A DC-DC converter acts as an interface between the load and the module as shown in figure 2. By changing the duty cycle, the load impedance as seen by the source varies and matches at the point of the peak power with the source so as to transfer the maximum power (Patel \& Agarwal 2008; Surya Kumari \& Sai Babu 2011; Faranda \& Leva 2008).

Consider a step down converter with output voltage $\mathrm{V}_{\mathrm{o}}$, Input voltage $\mathrm{V}_{\mathrm{i}}$ and duty cycle $\mathrm{D}$, it can be written as:

$$
\mathrm{V}_{\mathrm{o}}=\mathrm{D} * \mathrm{~V}_{\mathrm{i}} .
$$

With $\mathrm{R}_{\mathrm{O}}$ as output impedance and $\mathrm{R}_{\mathrm{i}}$ as input impedance, the impedance transfer equation becomes

$$
\begin{gathered}
\mathrm{R}_{\mathrm{o}}=\mathrm{D}^{2 *} \mathrm{R}_{\mathrm{i}}, \\
\text { and } \mathrm{R}_{\mathrm{i}}=\mathrm{R}_{0} / \mathrm{D}^{2} \text {. }
\end{gathered}
$$

Thus, the output resistances $\mathrm{R}_{\mathrm{O}}$ remains constant and by changing the duty cycle, the input resistance $\mathrm{R}_{\mathrm{i}}$ seen by the source, changes. Hence, the resistance corresponding to the peak power point is obtained by changing the duty cycle.

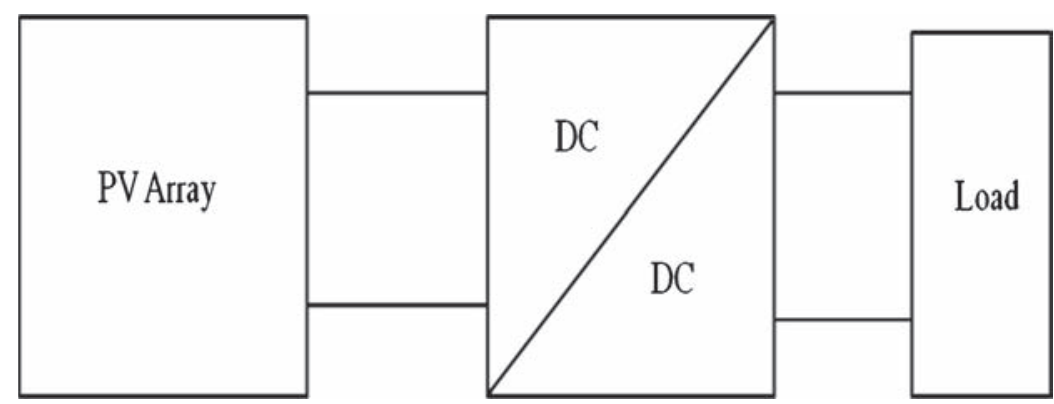

Figure 2. Basic block diagram of MPPT system. 


\section{Various MPPT algorithms}

By adjusting the duty cycle of DC-DC converter the source impedance can be made equal to output impedance and the peak power is reached. So, the question is reduced only to variation of duty cycle in a particular direction to reach to the peak power. There are various algorithms to perform this duty and these are:

(i) Perturb and Observe (P \& O)

(ii) Incremental Conductance (IC)

(iii) Fractional Open Circuit Voltage

(iv) Fractional Short Circuit Current

(v) Fuzzy Logic Control

Each of the algorithm has its own merits and demerits. Out of these algorithms two are most popular, i.e., Perturb and Observe (P \& O) and Incremental Conductance (IC) are discussed here in detail.

\subsection{Perturb and observe (Hill climbing method)}

In this method, as shown in figure 3, a slight perturbation is introduced in the system which changes the module power. If power increases due to perturbation it is continued in the same direction. When peak power is reached the next perturbation will give decrement in the power and perturbation reverses (Tariq et al 2011; MacIsaac \& Knox 2010). When steady state is reached, the algorithm oscillates around peak point. Perturbation size is generally kept small in order to keep the variation in power as small as possible. The algorithm is developed in such a manner that it sets a reference voltage of the module corresponding to the peak voltage of the module. A PI controller, then, acts moving the operating point of the module to that particular

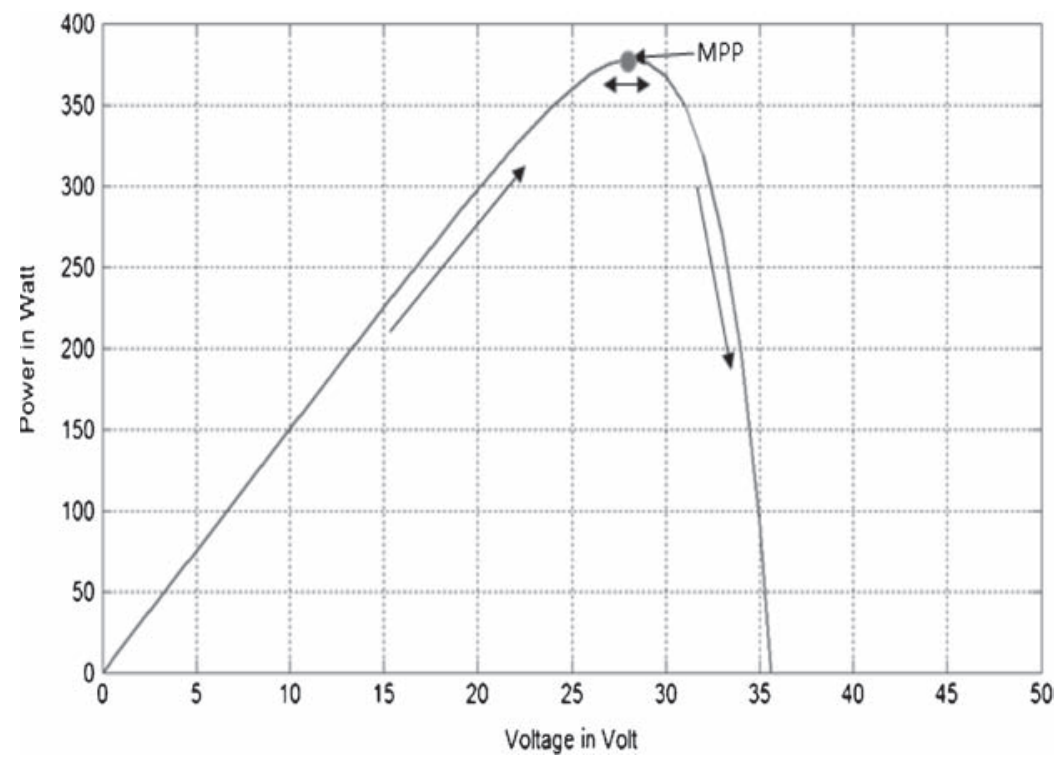

Figure 3. $P \& O$ Method. 
voltage level. It is also observed that some power loss due to this perturbation fails to track the power under fast varying atmospheric conditions. But still this algorithm is very popular and simple. The algorithm flow chart is shown in figure 4.

\subsection{Incremental conductance method}

The disadvantage of perturb and observe method to track the peak power under fast varying atmospheric conditions is overcome by incremental conductance method.

For a PV array, power equation can be written as

$$
\mathrm{P}=\mathrm{V}^{*} \mathrm{I}
$$

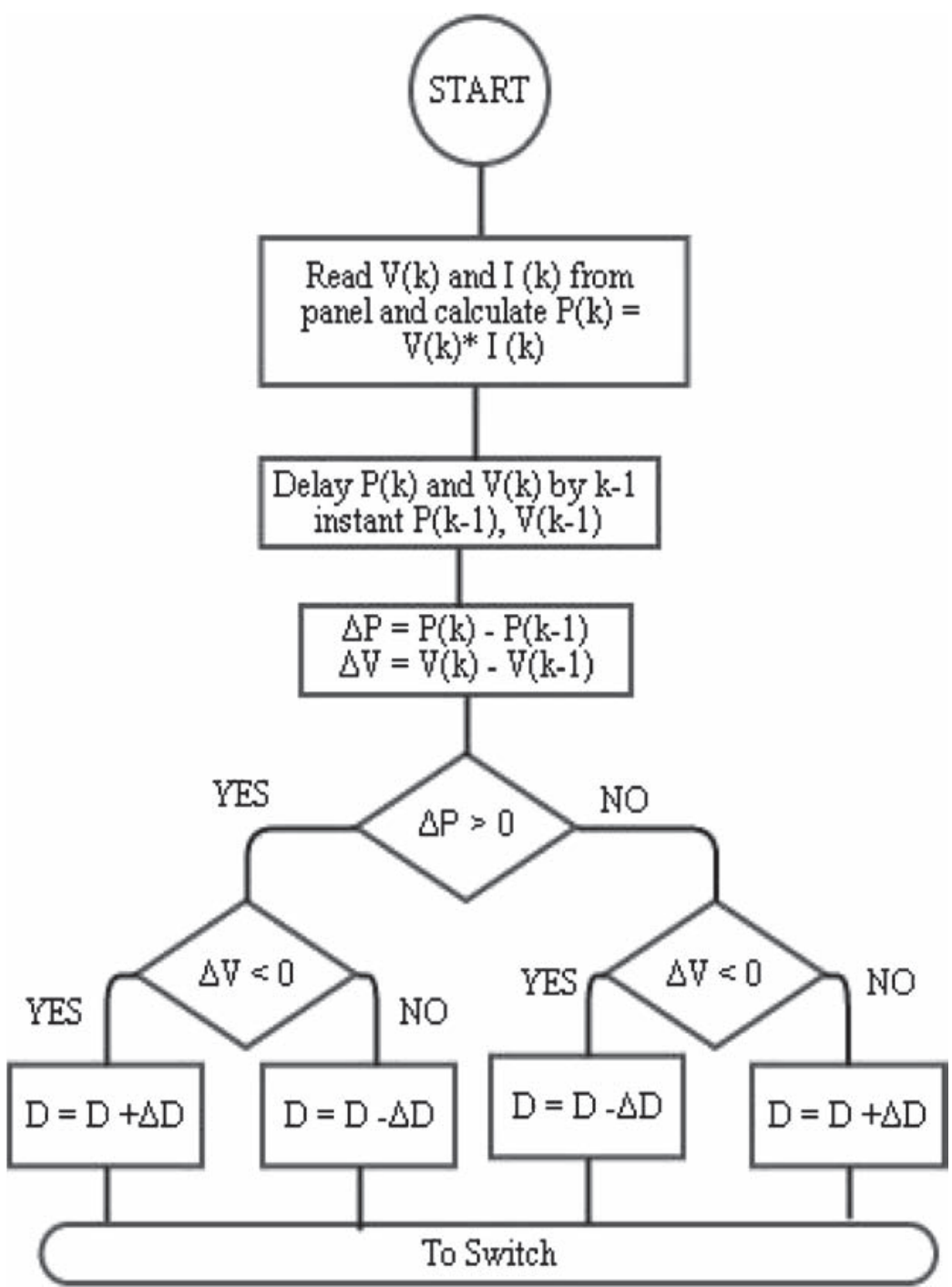

Figure 4. $\mathrm{P} \& \mathrm{O}$ Algorithm flow chart. 
(where $\mathrm{P}=$ module power, $\mathrm{V}=$ module voltage, $\mathrm{I}=$ module current);

Differentiating with respect to $\mathrm{V}$

$$
\mathrm{dP} / \mathrm{dV}=\mathrm{I}+\mathrm{V}^{*} \mathrm{dI} / \mathrm{dV}
$$

The whole algorithm works on the above equation.

At peak power point

$$
\begin{gathered}
\mathrm{dP} / \mathrm{dV}=0 \\
\mathrm{dI} / \mathrm{dV}=-\mathrm{I} / \mathrm{V} .
\end{gathered}
$$

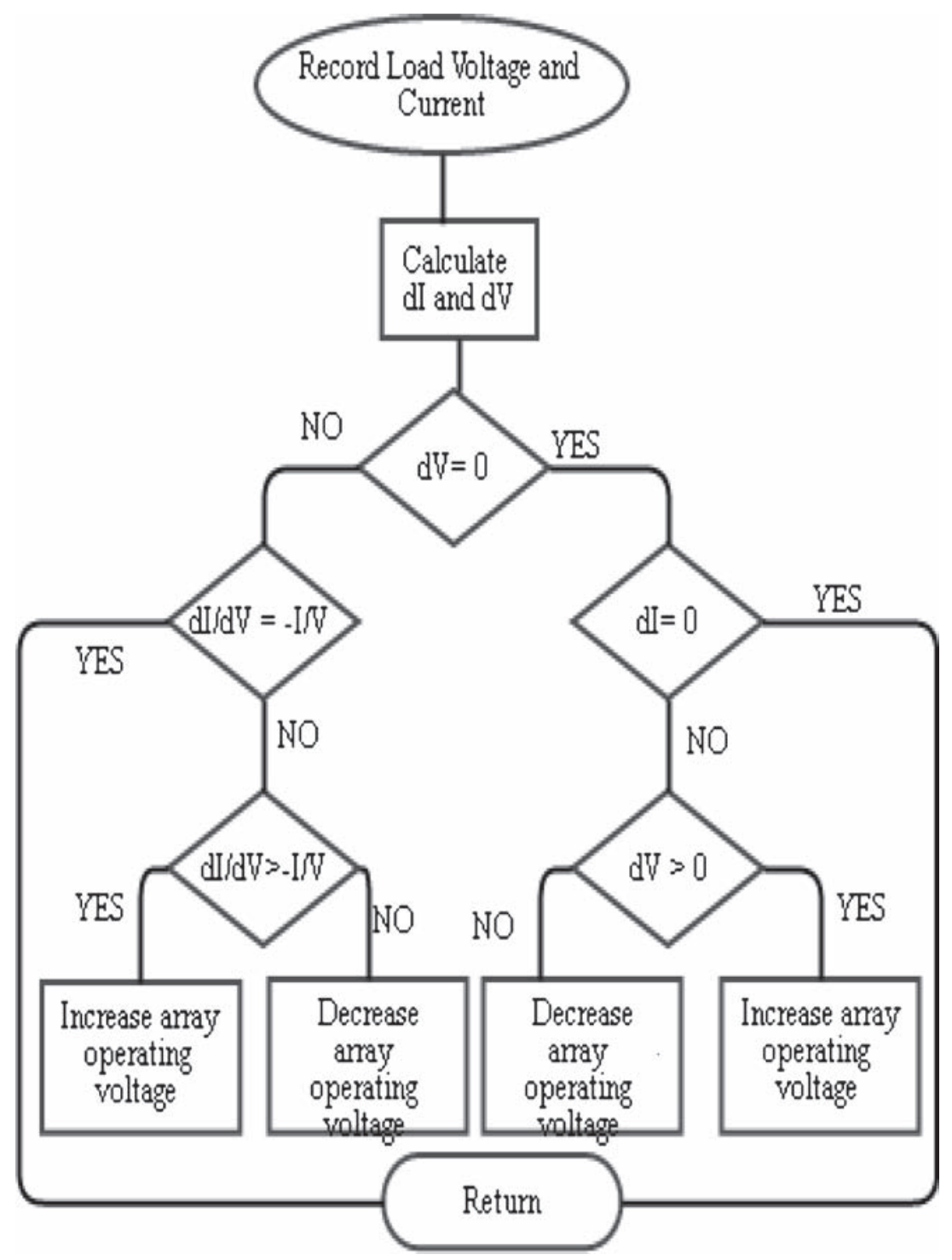

Figure 5. Incremental conductance algorithm flow chart. 
If the operating point is to the right of the Power curve, then we have

$$
\begin{gathered}
\mathrm{dP} / \mathrm{dV}<0 \\
\mathrm{dI} / \mathrm{dV}<\mathrm{I} / \mathrm{V} .
\end{gathered}
$$

If operating point is to the left of the power curve, then we have

$$
\begin{gathered}
\mathrm{dP} / \mathrm{dV}>0 \\
\mathrm{dI} / \mathrm{dV}>\mathrm{I} / \mathrm{V} .
\end{gathered}
$$

Using Eqs. (7), (9) and (10) the peak power can be tracked. This incremental conductance method is shown in figure 5 .

This algorithm has advantages over perturb and observe in that it can determine when the MPPT has reached the MPP, where perturb and observe oscillates around the MPP. Also, incremental conductance can track rapidly increasing and decreasing irradiance conditions with higher accuracy than perturb and observe. One disadvantage of this algorithm is the increased complexity when compared to perturb and observe as it requires two sensors Viz. Current and Voltage whereas P \& O method requires just one sensor and that is Voltage only. Flow chart of incremental conductance method is shown in figure 6.

\section{Modelling PV solar cell}

Studies have shown that Maximum Power Point (MPP) varies with solar insolation and temperature (Tsai et al 2008; Bruendlinger et al 2007). To understand this concept of variation of MPP, to model the solar cell is prerequisite. Figure 7 shows basic model of solar cell. For the model shown in above figure, $I_{P H}$ indicates Photon current, $I_{D}$ represents diode current, $R_{p}$ represents parallel resistance accounted for leakage effect, $I_{R P}$ shows current passing through $R_{p}, R_{s}$ is the series resistance which creates losses and it is accounted for contact and material properties, $\mathrm{I}$ is the load current, $R_{L}$ is the load resistance and $V$ is the voltage across $R_{L}$.

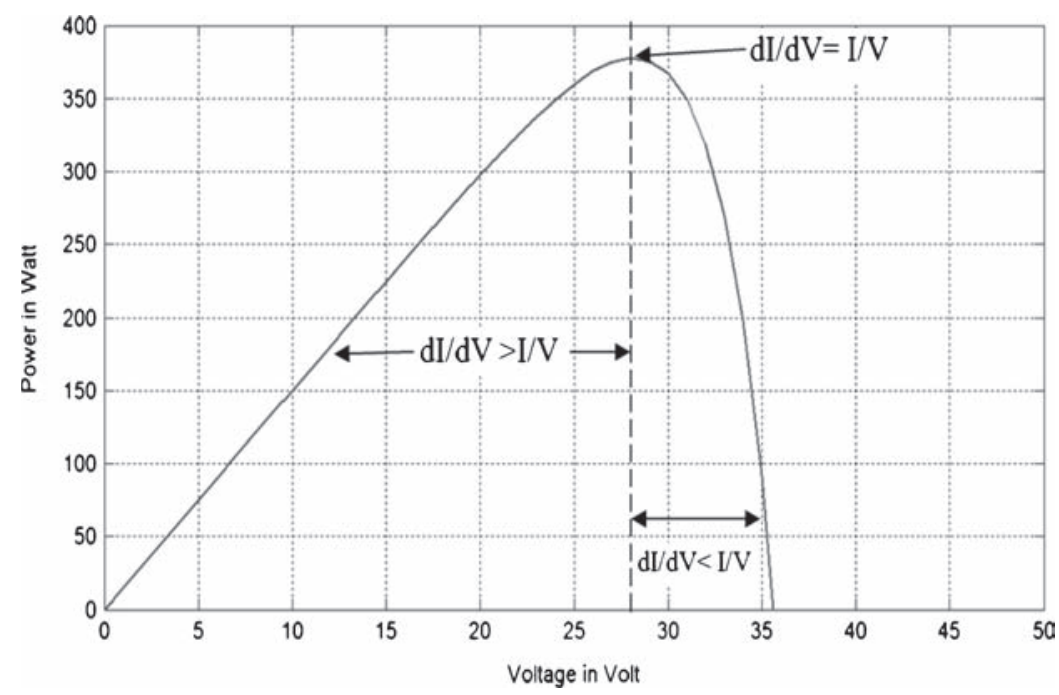

Figure 6. Incremental conductance method. 


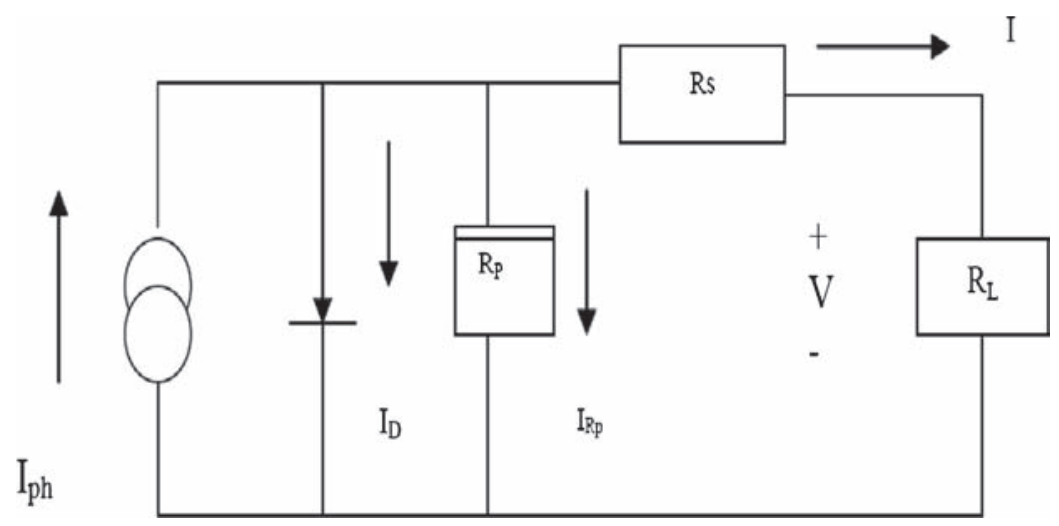

Figure 7. Basic model of solar cell.

For the model shown in figure 7 the mathematical equations can be written as

$$
\begin{gathered}
\mathrm{I}_{\mathrm{PH}}=\mathrm{I}+\mathrm{I}_{\mathrm{RP}}+\mathrm{I}_{\mathrm{D}} . \\
\text { Therefore, } \mathrm{I}=\mathrm{I}_{\mathrm{PH}}-\mathrm{I}_{\mathrm{RP}}-\mathrm{I}_{\mathrm{D}} \\
\mathrm{I}_{\mathrm{RP}} \text { is given by } \mathrm{I}_{\mathrm{RP}}=I o *\left[\exp \left(V+\frac{I R s}{V t}\right)-1\right],
\end{gathered}
$$

where $I_{0}$ is the reverse saturation current and $V_{t}$ is thermal voltage equal to $\mathrm{kT} / \mathrm{q}$ with $\mathrm{k}$ as Boltzman constant, $\mathrm{T}$ as temperature in Kelvin and $\mathrm{q}$ as electron charge.

$$
\mathrm{I}_{\mathrm{D}} \text { is given by } \mathrm{I}_{\mathrm{D}}=\left(\mathrm{V}+\mathrm{IR}_{\mathrm{S}}\right) / \mathrm{R}_{\mathrm{P}}
$$

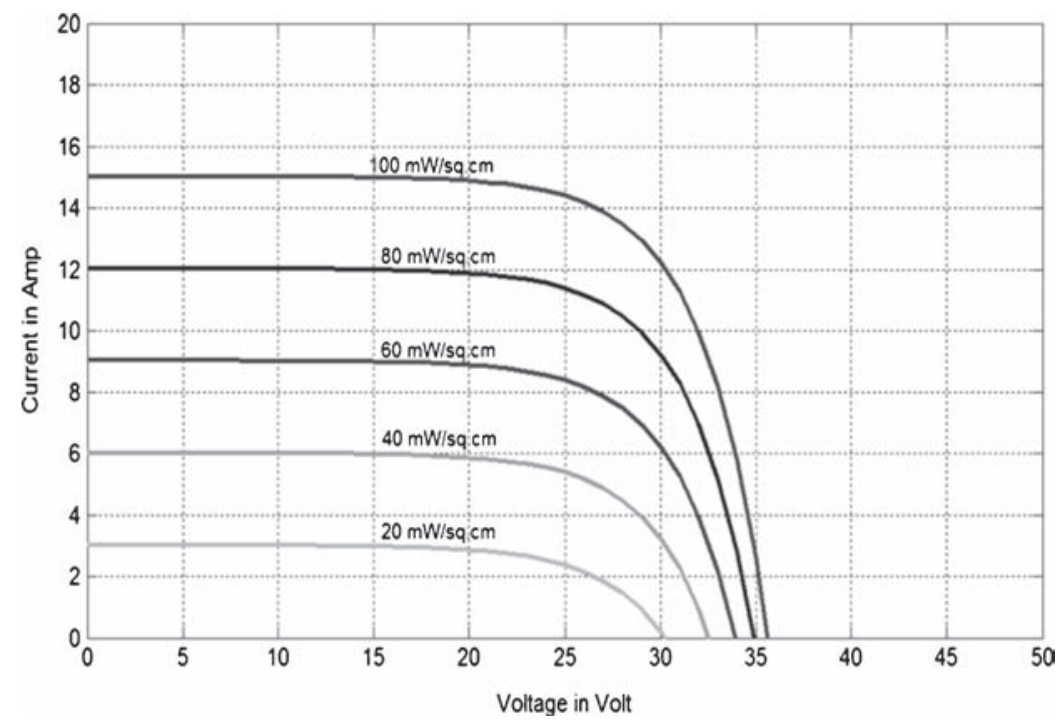

Figure 8. V-I Cha. For Solar Array and variation of MPP with Solar Irradiation (temperature $28^{\circ} \mathrm{C}$ constant). 


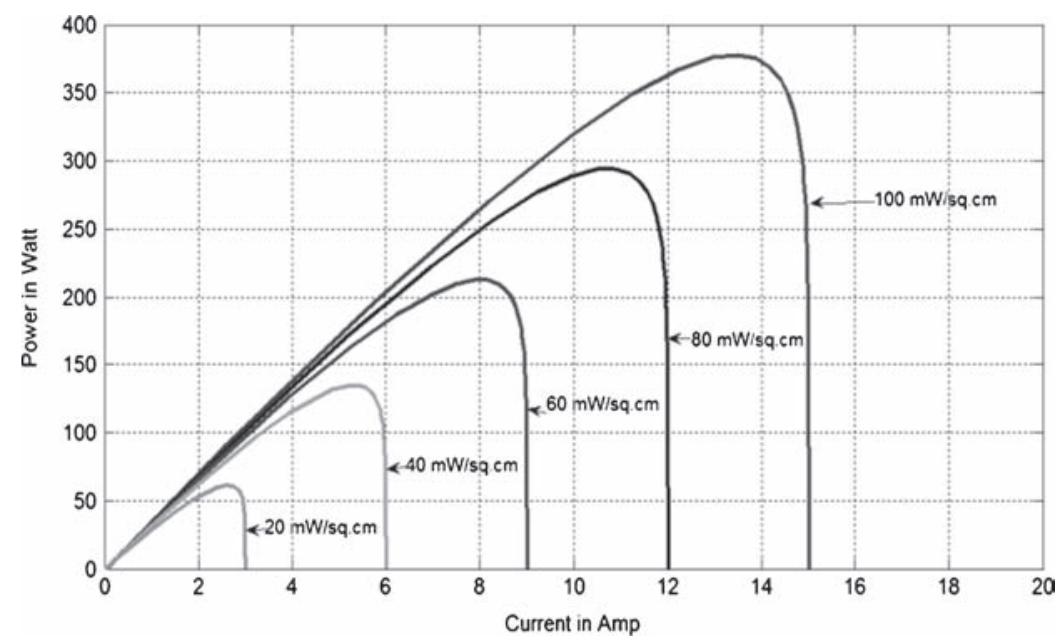

Figure 9. P-I Cha. For solar array and its variation with solar irradiation (temperature $28^{\circ} \mathrm{C}$ constant).

Putting (16) and (17) in to (15)

$$
\mathrm{I}=\mathrm{I}_{\mathrm{PH}}-I o *\left[\exp \left(V+\frac{I R s}{V t}\right)-1\right]-\left(\mathrm{V}+\mathrm{IR}_{\mathrm{s}}\right) / \mathrm{R}_{\mathrm{p}}
$$

For solar array with $\mathrm{N}_{\mathrm{p}}$ no. of cells in Parallel and $\mathrm{N}_{\mathrm{s}}$ no. of cells in series to increase current and voltage rating of array,

$$
\mathrm{I}=\mathrm{N}_{\mathrm{p} *} \mathrm{I}_{\mathrm{PH}}-\mathrm{N}_{\mathrm{p} *} \mathrm{I}_{\mathrm{r} * *}\left[\exp \left(\frac{q}{k T A}+\frac{V}{N s}\right)-1\right],
$$

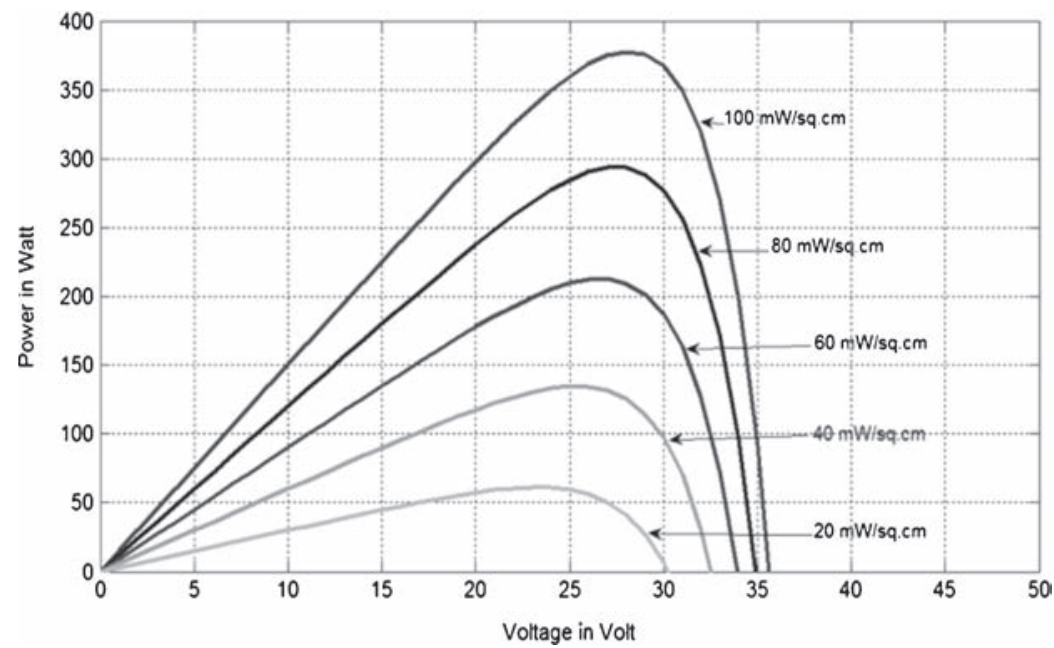

Figure 10. P-V Cha. For solar array and its variation with solar irradiation (temperature $28^{\circ} \mathrm{C}$ constant). 


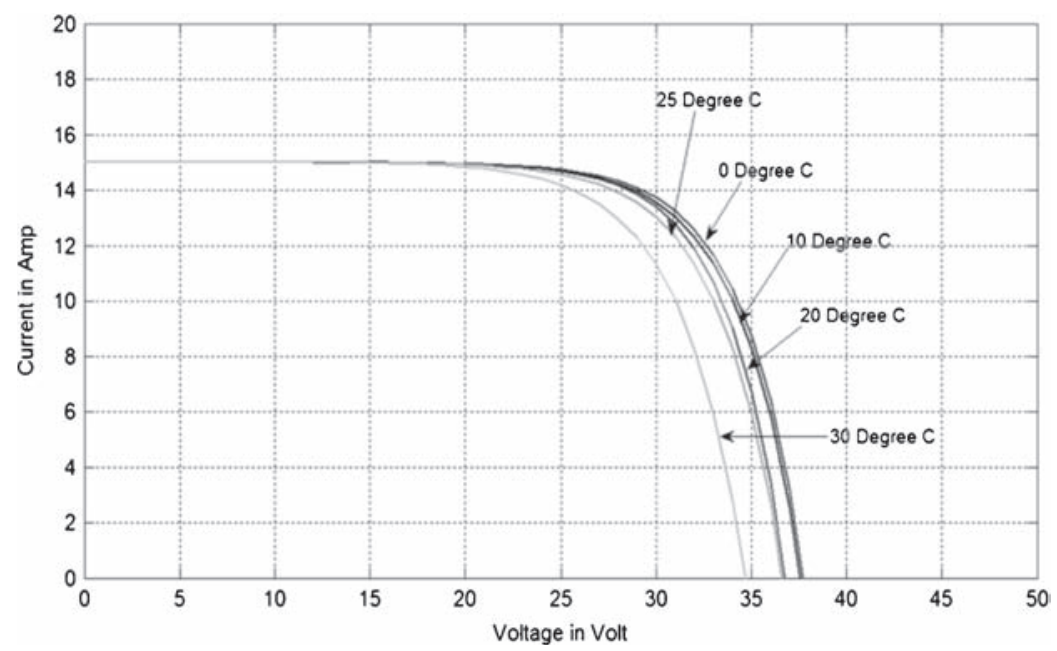

Figure 11. V-I Cha. For Solar Array and variation of MPP with temperature (solar irradiation $100 \mathrm{~mW} / \mathrm{sq} . \mathrm{cm}$ constant).

where $\mathrm{I}_{\mathrm{rs}}$ is given by

$$
\begin{aligned}
\mathrm{I}_{\mathrm{rs}} & =\mathrm{I}_{\mathrm{rr}}^{*}[T / T r]^{3}\left[\exp \left(\frac{q E g}{k A}\left[\frac{1}{T r}+1\right]\right)\right] \\
\text { and } \mathrm{P} & =\mathrm{V}^{*} \mathrm{I}=\mathrm{N}_{\mathrm{p} *} \mathrm{I}_{\mathrm{PH} *} \mathrm{~V}\left[\left(\mathrm{q} / \mathrm{kTA}^{*} \mathrm{~V} / \mathrm{N}_{\mathrm{s}}\right)-1\right]
\end{aligned}
$$

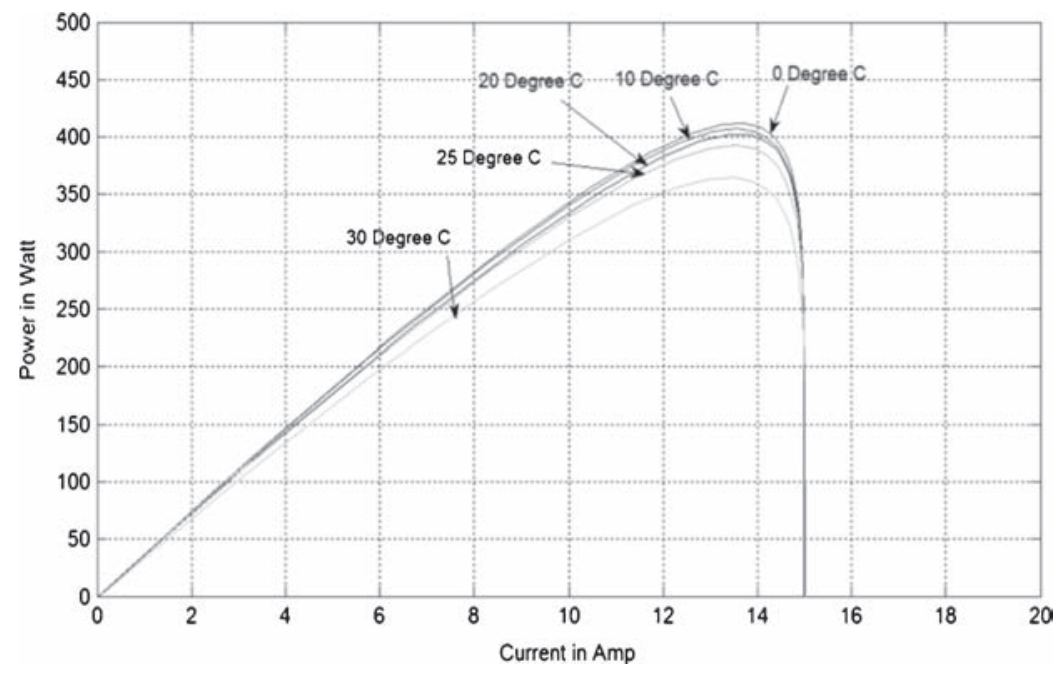

Figure 12. P-I Characteristics. For Solar Array and variation of MPP with temperature (solar irradiation $100 \mathrm{~mW} / \mathrm{sq} . \mathrm{cm}$ constant). 


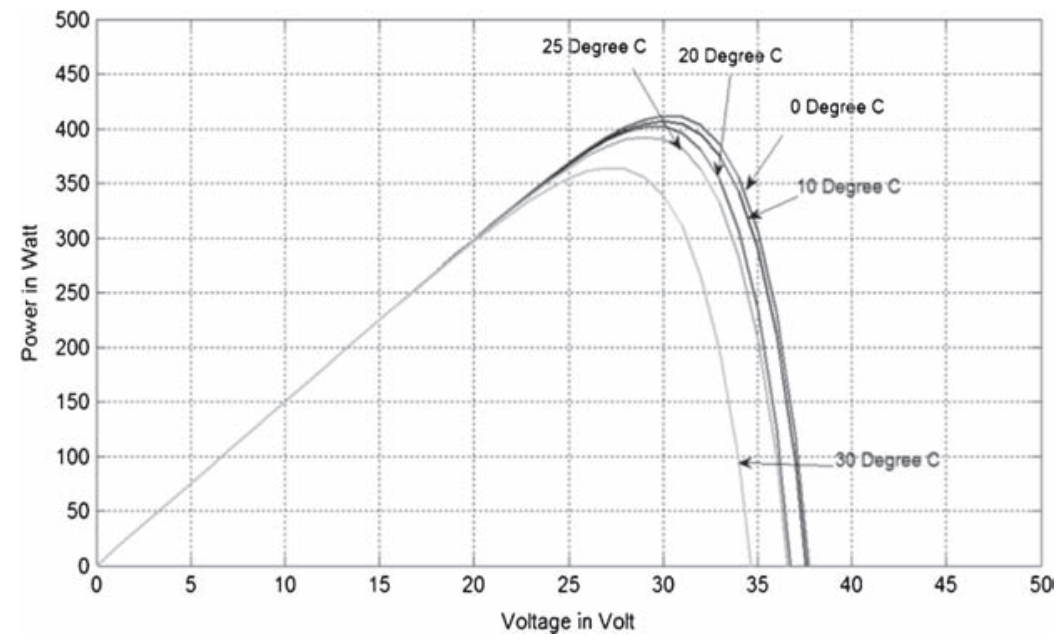

Figure 13. P-V Cha. For solar array and variation of MPP with temp. (solar irradiation $100 \mathrm{~mW} / \mathrm{sq} . \mathrm{cm}$ constant).

where, $\operatorname{Tr}$ is the reference temperature, Eg is the band gap energy and Irr is the reverse saturation current of cell at $\mathrm{T}_{\mathrm{r}}$. The photon current $\mathrm{I}_{\mathrm{PH}}$ depends upon solar irradiation and temperature as follows:

$$
\mathrm{I}_{\mathrm{PH}}=\left[\mathrm{I}_{\mathrm{scr}}+\mathrm{K}_{\mathrm{i}}\left(\mathrm{T}-\mathrm{T}_{\mathrm{r}}\right)\right]^{*} \mathrm{~S} / 100,
$$

where $\mathrm{s}$ is the solar irradiation in $\mathrm{mW} / \mathrm{sq}, \mathrm{cm}$.

Considering Eqs. (12) to (14), MATLAB M-file was created to see the variation of MPP with solar irradiation and temperature. The results of MATLAB programme are shown from figures 8 to 13 .

Table 1. MPPT system parameters.

Solar panel model

Solar panel wattage

Open circuit voltage for panel

Voltage at MPP for panel

Short circuit current for panel

Current at MPP for panel

No. of panels in series

No. of panels in parallel

Total power of system at MPP

Boost converter output voltage

Grid voltage (Through X'mer)

Boost converter inductance

Boost converter switching frequency

Filter inductance

Inverter

Grid length

Grid load
Sun Power SPR-305

305 Watt (Wp)

64.2 Volt

54.7 Volt

$5.96 \mathrm{~A}$

$5.57 \mathrm{~A}$

5

66

$305 * 66 * 5=100.65 \mathrm{~kW}$

500 Volt

$50 \mathrm{kVA}, 500 \mathrm{~V} / 25 \mathrm{kV}$

$5 \mathrm{mH}$

$5 \mathrm{kHZ}$

$250{ }^{\mu} \mathrm{H}$

3 Level VSC

$19 \mathrm{~km}$. (pi section)

32 MW, 2 MVar 


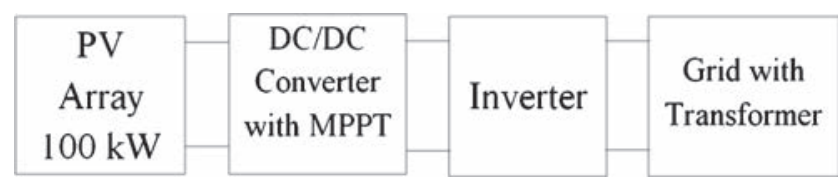

Figure 14. Simulated system.

\section{Simulation of $100 \mathrm{~kW}$ grid connected solar system}

After simulating the solar cell and understanding the basic functionality of the two most popular MPPT algorithms, viz. (i) Perturb and Observe (P \& O) and (ii) Incremental conductance algorithm, these algorithms are simulated for a $100 \mathrm{~kW}$ grid connected solar system. The
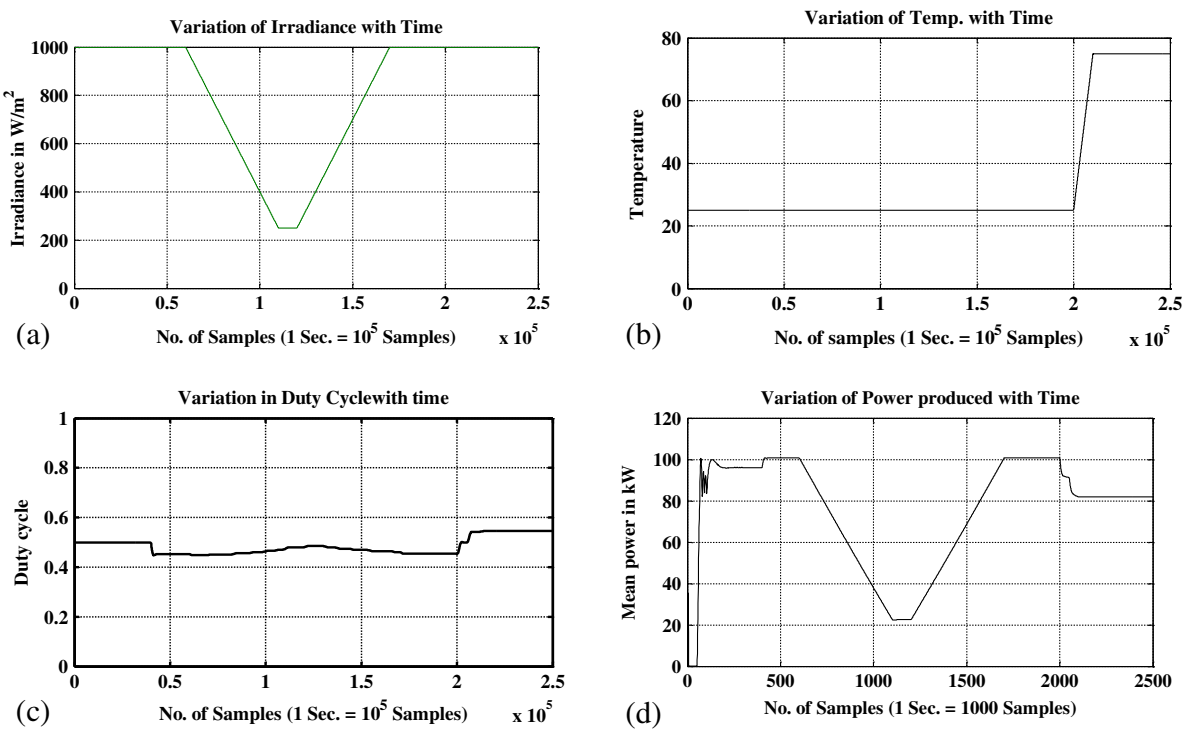

(c)

(d)
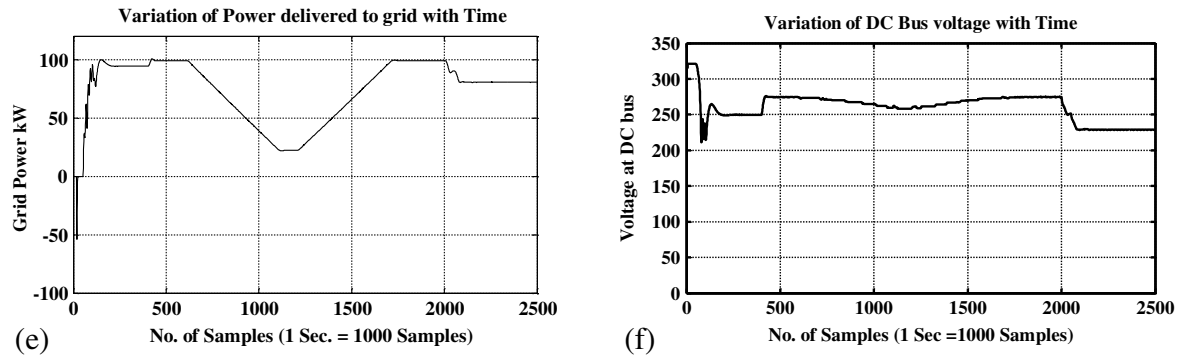

Figure 15. (a). Variation of irradiance with time for incremental conductance algorithm. (b) Variation of temperature with time for incremental conductance algorithm. (c) Variation of duty cycle with time for incremental conductance algorithm. (d) Variation of power produced by pv panel with time for incremental conductance algorithm. (e) Variation of power delivered to the grid with time for incremental conductance algorithm. (f) Variation of DC bus voltage with time for incremental conductance algorithm. 
parameters of the system are shown in table 1. Simulation circuit block diagram is shown in figure 14.

\subsection{Simulation results}

For the system and parameters shown above, the simulations were carried out using MATLAB/Simulink software. Two algorithms: (i) Perturb and Observe (P \& O) and (ii) Incremental Conductance were implemented in simulations. The effect of variation in insolation and temperature were observed in the simulation results and based on this, a comparison is made between above said algorithms. The results are presented from figure 15a to $\mathrm{f}$ for incremental conductance algorithm and figure 16 a to $\mathrm{f}$ for $\mathrm{P} \& \mathrm{O}$ algorithm. To compare the two algorithms with respect to fastness of response, duty cycle, power generated by PV panel and delivered to the grid and variation of DC bus voltage their total time of simulation was kept constant. i.e., 2.5 seconds.
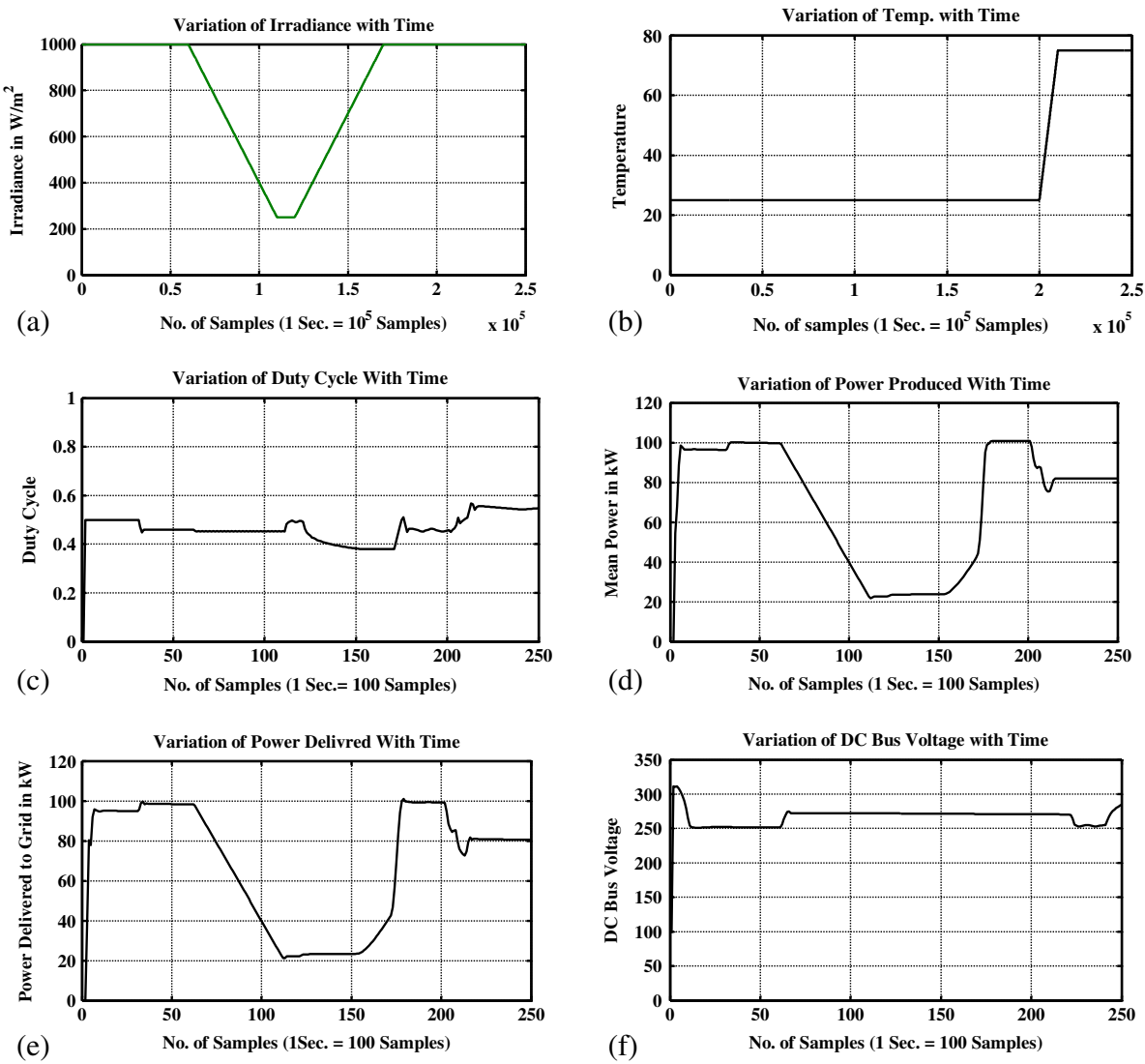

Figure 16. (a). Variation of irradiance with time for perturb and observe algorithm. (b) Variation of temperature with time for perturb and observe algorithm. (c) Variation of duty cycle with time for Perturb and observe algorithm. (d) Variation of power produced by PV panel with time for Perturb and observe algorithm. (e) Variation of power delivered to the grid with time for perturb and observe algorithm. (f) Variation of DC bus voltage with time for Perturb and observe algorithm. 


\subsection{Simulation results comparison}

As can be seen from figures $15 \mathrm{a}$ and $\mathrm{b}$ and $16 \mathrm{a}$ and $\mathrm{b}$, the temperature and solar insolation were kept same for both the algorithms. The following points are important to note for comparison.

\begin{tabular}{|c|c|c|}
\hline Parameter & Incremental conductance & Perturb and observe \\
\hline Duty cycle & Variation is steady & $\begin{array}{l}\text { Fluctuations are very high, } \\
\text { especially at the points } \\
\text { where temperature or } \\
\text { insolation changes, is more } \\
\text { pronounced }\end{array}$ \\
\hline $\begin{array}{l}\text { PV power } \\
\text { output }\end{array}$ & $\begin{array}{l}\text { Change is very fast } \\
\text { and it follows } \\
\text { change in insolation }\end{array}$ & $\begin{array}{l}\text { Response is sluggish and it } \\
\text { follows change in insolation } \\
\text { after some time }\end{array}$ \\
\hline $\begin{array}{l}\text { Power } \\
\text { delivered to } \\
\text { the grid }\end{array}$ & $\begin{array}{l}\text { Change is very fast } \\
\text { and it nearly follows } \\
\text { change in insolation }\end{array}$ & $\begin{array}{l}\text { Response is sluggish and it } \\
\text { follows change in insolation } \\
\text { after some time. w.r.t. } \\
\text { incremental conductance } \\
\text { this is slow by nearly } 0.2 \text { Seconds }\end{array}$ \\
\hline $\begin{array}{l}\text { DC bus } \\
\text { voltage }\end{array}$ & Moderate variation & $\begin{array}{l}\text { Smaller variation gives } \\
\text { nearly a steady graph }\end{array}$ \\
\hline
\end{tabular}

\section{Conclusion}

The basic concept of solar maximum power point tracking with power electronics based systems is presented here. Two most popular algorithms are discussed with their relative merits and demerits. Solar cell modelling is done using mathematical equation and MATLAB simulations are shown for PV array for validation of the fact that MPP varies with solar irradiation and temperature. Solar insolation values of 20, 40, 60, 80 and $100 \mathrm{~mW} / \mathrm{sq} . \mathrm{cm}$. were considered for simulations of open circuit P-V, V-I and P-I characteristics at $28^{\circ}$ centigrade temperature and similarly with constant solar insolation of $100 \mathrm{~mW} / \mathrm{sq}$. cm P-V, V-I and P-I characteristics are drawn at $0,10,20,25$ and 30 degree centigrade temperatures. The comparison for (a) Incremental conductance and (b) Perturb and Observe algorithm suggests clearly that for varying nature of atmosphere, incremental conductance gives better performance than Perturb and Observe algorithm.

\section{References}

Armstrong S and Hurley W G 2004 Self-regulating maximum power point tracking for solar energy systems Universities Power Engineering Conference, 39th International IEEE September: 604-609

Azab Mohamed 2008 A New Maximum Power Point Tracking for Photovoltaic Systems World Academy of Science. Engineering and Technology Proceeding: 471-474

Bruendlinger Roland, Benoît Bletterie, Matthias Milde and Henk Oldenkamp 2007 Maximum Power Point Tracking Performance Under Partially Shaded PV Array Conditions OTTI PV- Symposium, Staffelstein, Germany: 141-144 
Chaudhari Vikrant A 2005 Automatic Peak Power Tracker For Solar PV Modules Using DSpace Software Thesis Submitted in partial fulfillment of the Requirement for the award of the Degree of Master Of Technology Maulana Azad National Institute of Technology

Das Debashis and Pradhan Shishir Kumar 2005 Modeling and Simulation of Pv Array With Boost Converter: An Open Loop Study: a Thesis in Partial Fulfillment of Requirements for The Award of The Degree of Bachelor of Technology, National Institute of Technology. Rourkela 1-56

Enslin Johan H R, Wolf Mario S, Snyman Daniël B and Swiegers Wernher 1997 Integrated Photovoltaic Maximum Power Point Tracking Converter. IEEE Transactions on Industrial Electronics 44(6): 769-773

Faranda Roberto and Leva Sonia 2008 Energy Comparison of Mppt Techniques For PV Systems WSEAS. Transactions on Power Systems 6(3): 446-455

Hohm D P 2000 Comparative Study of Maximum Power Point Tracking Algorithms Using an Experimental, Programmable, Maximum Power Point Tracking Test Bed Photovoltaic Specialists Conference. Conference Record of the Twenty-Eighth IEEE: 1699-1702

Kachhiya Kinal, Lokhande Makarand and Patel Mukesh 2011 MATLAB/Simulink Model of Solar PV Module and MPPT Algorithm National Conference on Recent Trends in Engineering \& Technology 13-14 May B.V.M. Engineering College, V.V. Nagar, Gujarat, India

MacIsaac L and Knox A 2010 Improved Maximum Power Point Tracking Algorithm for Photovoltaic Systems International Conference on Renewable Energies and Power Quality (ICREPQ'10) Granada (Spain), 239-244

Patel H and Agarwal V 2008 Maximum Power Point Tracking Scheme for PV Systems Operating Under Partially Shaded Conditions Industrial Electronics. IEEE Transactions on April 55(4): 1689-1698

Surya Kumari J and Sai Babu Ch 2011 Comparison Of Maximum Power Point Tracking Algorithms for Photovoltaic System. Int. J. Advances in Eng. Technol. 133-148

Szczesny P M, Steigerwald R L and Bose B K 1985 Microcomputer Control of a Residential Photovoltaic Power Condictioning System Industry Applications. IEEE Transactions IA-21(5): 1182-1191

Tariq Abu, Asim Mohammed and Tariq Mohd 2011 Simulink based modeling, simulation and Performance Evaluation of an MPPT for maximum power generation on resistive load 2nd International Conference on Environmental Science and Technology, IPCBEE vol.6- IACSIT Press. Singapore 2: 397-401

Tsai Huan-Liang, Tu Ci-Siang and Su Yi-Jie 2008 Development of Generalized Photovoltaic Model Using MATLAB/Simulink Proceedings of the World Congress on Engineering and Computer Science San Francisco, USA, pp 331-336

Xiao Weidong 2011 Overview of maximum power point tracking technologies for photovoltaic power systems IECON 2011 - 37th Annual Conference on IEEE Industrial Electronics Society 7-10 November 2011: 3900-3905 